\title{
Monitoring Cadmium Concentrations in Sediments and Aquatic Insects (Hydropsychidae: Trichoptera) in a Stream near a Zinc Mining Area
}

\author{
Taeng On Prommi*, Ampon Payakka \\ Faculty of Liberal Arts and Science, Kasetsart University, Kamphaeng Saen Campus, \\ Nakhon Pathom Province, Thailand
}

Received: 28 July 2017

Accepted: 14 October 2017

\begin{abstract}
Aquatic insects can accumulate pollutants such as cadmium from stream sediments. This research aimed to monitor cadmium concentrations in both larvae and adult Hydropsychidae (Trichoptera, Insecta) in Mae Tao (MT1 to MT5) and Mae Ku (MK2 and MK8) watersheds in northern Thailand. Samples were collected twice a month from July 2011 to May 2012 at seven sampling sites. The cadmium concentrations in the stream sediments ranged from 0.12 to $21.5 \mathrm{mg} \mathrm{kg}^{-1}$ wet weight. The highest concentration was recorded from the MT3 sampling site $\left(21.5 \mathrm{mg} \mathrm{kg}^{-1}\right)$, which is also closest to a mining area. The lowest concentration was recorded from the MK2 sampling site $\left(0.12 \mathrm{mg} \mathrm{kg}^{-1}\right)$. Cadmium concentrations in both larvae and adult Hydropsychidae were not significantly different at all sampling sites. However, the cadmium concentrations in Hydropsychidae larvae that ranged from $0.07-1.70 \mathrm{mg} \mathrm{kg}^{-1}$ were higher than the detected cadmium in adult samples (average $0.020 \mathrm{~m} \mathrm{~kg}^{-1}$ ). There was no significant correlation between cadmium concentrations in sediments, and in both larvae and adult Hydropsychidae. Concentrations of cadmium in adult Hydropsychidae in this study were low. Even though the contamination of heavy metals was low in adult Hydropsychidae, long-term exposure to heavy metals could seriously impact terrestrial animals such as birds and bats that consume these insects.
\end{abstract}

Keywords: cadmium, aquatic insects, sediment, mining area

\section{Introduction}

Cadmium $(\mathrm{Cd})$ is considered one of the most toxic heavy metals, and is a non-essential element to all living organisms [1]. It is usually found together with zinc ore and is recovered as a by-product of zinc mining [2]. Cadmium from industrial discharges is deposited into different components of the aquatic ecosystem such as water bodies, suspended particulate matter,

*e-mail: faastop@ku.ac.th sediment, and biota [3]. Consequently, cadmium can be accumulated and magnified in aquatic insect tissue through ingesting food and via water. Cadmium, even at very low concentrations, can be strongly accumulated through the aquatic food-web [4-5]. Many small aquatic organisms spend the majority of their life-cycle in water, living on or in sediments, and may provide a pathway for chemicals to be accumulated and consumed by higher organisms [6]. Adult aquatic insects, which form a significant portion of the diet of some terrestrial organisms [7], inevitably emerge from contaminated sediments and transfer body burden to the terrestrial 
environment either directly as prey items to insectivores, or indirectly through the detritus food chain [8]. A number of studies [9-10] have shown that both immature and emerging insects play a crucial role in determining metal contaminants in the environment. Currie et al. [11] collected emerging insects (Diptera, Odonata, Ephemeroptera, and Trichoptera) from lake water in order to quantitatively estimate the export of cadmium by aquatic insects from a natural system having elevated cadmium concentrations in the water and sediment.

In the Mae Tao watershed, Mae Sot District, Tak Province, Thailand, cadmium residues were found in the environment and in products such as rice, aquatic animals, and drinking water, which is likely due to nearby mineral extraction activities [12]. These activities include drilling, material transfer, and the removal of mine tailings and drainage [13]. Simmons et al. [14] studied the cadmium concentrations of 154 soil samples collected from the Huai Mae Tao area and found cadmium levels in rice field soils of $3.40-284 \mathrm{mg} \mathrm{kg}^{-1}$ soil, which is 94 times higher than the European Economic Community's maximum permissible concentration in soil (3 $\mathrm{mg} \mathrm{kg}^{-1}$ soil) [14]. Krissanakriangkrai et al. [15] investigated the magnitude of cadmium pollutants in water, sediment, fish, and shellfish from nine sites along Mae Tao Creek. They found that cadmium levels in the river sediment exceeded the allowable standard. The highest concentrations of cadmium were detected in Swamp eel $\left(0.27 \mathrm{mg} \mathrm{kg} \mathrm{kg}^{-1}\right.$ wet weight). Concentrations of cadmium in pond snail were $0.13 \mathrm{mg} \mathrm{kg}^{-1}$ wet weight. In the same year, Othman et al. [16] determined that cadmium accumulation and bioconcentration factors affect the whole organism. The liver, kidney, ovary, and testis of Fejervarya limnocharis are exposed to different environmental cadmium levels. Frogs from contaminated sites had significantly higher hepatic (1.939 $\left.\mathrm{mg} \mathrm{kg}^{-1}\right)$, renal $\left(7.253 \mathrm{mg} \mathrm{kg}^{-1}\right)$, and testicular (1.462 $\mathrm{mg} \mathrm{kg}^{-1}$ ) cadmium levels than those from the reference sites $\left(0.205,0.783\right.$, and $0.379 \mathrm{mg} \mathrm{kg}^{-1}$, respectively).

Trichoptera (also known as caddisfly) is one of the largest groups of aquatic insects. They are holometabolous insects with aquatic larvae and pupae with terrestrial adults [17]. Most species of caddisfly in the Hydropsychidae family spend their larval lives in running water and have been reported to be excellent bioindicators of trace element pollution in aquatic ecosystems [18]. They take up trace elements directly from water, sediments, and diet, and serve as a trophic link to higher food chain organisms such as fish and aquatic birds [19]. Therefore, this study aimed to monitor cadmium concentrations in both larvae and adult Hydropsychidae, and cadmium concentrations in stream sediments in close proximity to zinc mines. The Huai Mae Tao site runs through a mine, whereas the Huai Mae Ku site has a mine parallel to the stream.

\section{Materials and Methods}

\author{
Study Area
}

Mae Tao and Mae $\mathrm{Ku}$ watersheds are located in the lower part of Mae Sot district, Tak Province, northern Thailand, in the mountain area of the border between Thailand and Myanmar. Mae Tao Stream is vital for life in Mae Sot District and is the main freshwater resource for many villages, meeting nearly all the demands for drinking water, irrigation, and agricultural. There is the zinc mine upstream of Mae Tao Stream. The zinc mine began operating in 1982, and this area has been affected by the adverse impacts of heavy metals, especially cadmium. Cadmium contamination has been reported in rice, soil, and sediment in and around Mae Tao Stream $[14,20]$. About $69.2 \%$ of the sediment samples of the stream exceeded the European maximum permissible level of $3.0 \mathrm{mg} \mathrm{kg}{ }^{-1}$ [21-23]. Cadmium concentrations were low in the sediments before reaching the zinc area, but became much higher when the stream passed through this area.

The seven sampling sites were selected from both watersheds in this study. Study sites in the Mae Tao watershed (MT1, MT2, MT3, MT4, and MT5; Fig. 1) run through a mine, while MK2 and MK8 both flow parallel to the mentioned stream located in Mae $\mathrm{Ku}$ watershed, which is surrounded by agricultural areas. The main agricultural products in this area are rice, soybean, sugar cane, and garlic. Mining activity contributes significantly to metal contamination due to the discharge and the natural spread of mine wastes by wind, water, and rainfall into adjacent agriculture soils, food crops, and water ecosystems [24]. The streams from Mae Tao and Mae Ku watersheds flow to the Moei River - a $327 \mathrm{~km}$-long borderline between Myanmar and Thailand. At each site, the sample was collected two times per month from July 2011 to May 2012.

\section{Sample Collection}

Hydropsychidae larvae are distinguished from all other caddisfly larvae by the sclerotization of the dorsum of each thoracic segment and branched gills on the ventral surface of the abdomen and the last two thoracic segments, usually with a tuft of long setae near the apex of each anal proleg [25]. The sclerotized plates of the mesonotum and metanotum do not have a median dorsal ecdysial line, although the line does occur on the pronotal plates; in some subfamilies, the last two thoracic notal sclerites have a transverse ecdysial suture [25]. Hydropsychidae larvae for cadmium analysis were collected using a D-frame aquatic net (mesh sieve 250 $\mu \mathrm{m})$, as described in Prommi and Permkam [26], and by hand from the surfaces of stones, stone crevices, gravel, and woody debris at each collection site. Samples were collected until there was enough biomass for laboratory analysis (at least $2.0 \mathrm{~g}$ ). Specimens were immediately 
categorized into family level upon sample collection, frozen using dry ice, and then kept on ice during transportation to the laboratory in order to perform cadmium analysis. Additionally, at each collection site adults were collected using portable blacklight traps
(10-W fluorescent tube, 12-volt DC battery) suspended across a white pan containing a detergent solution.

Surface sediments were collected from the same depositional areas of shallow, slow-moving water near the water's edge forming one composite sample.
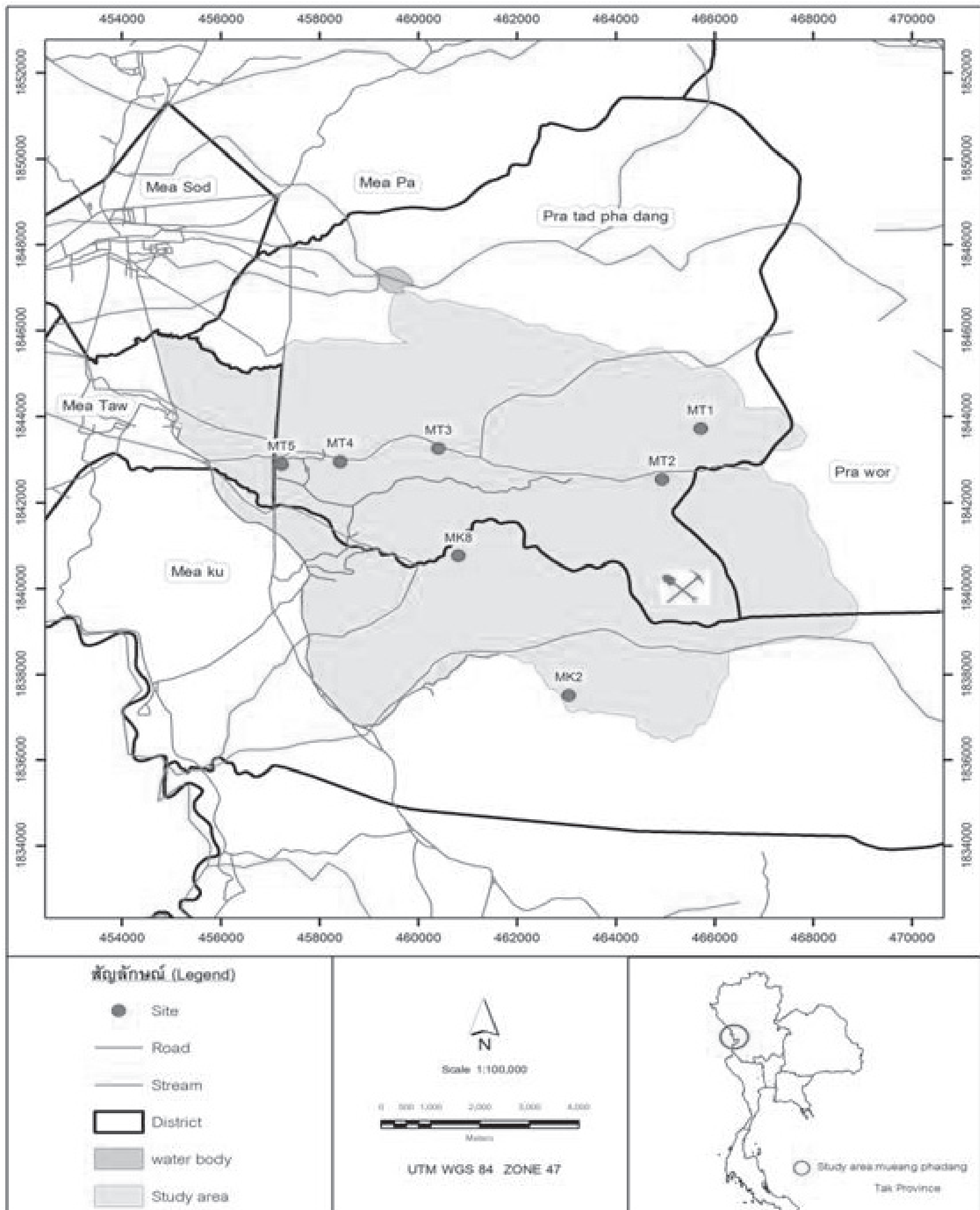

Sale 1:100.009

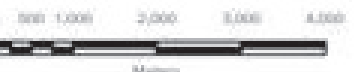

UTM WaS 84 ZONE 47

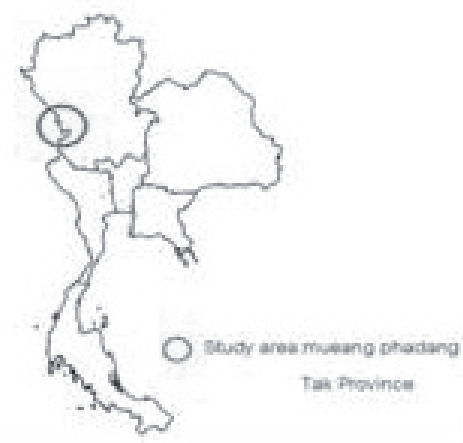

Fig. 1. Map showing the sampling stations (MT1-MT5, MK2, MK8) at Mae Tao and Mae Ku watersheds. 
Table 1. Mean \pm SD cadmium concentration in stream sediment, and both larvae and adult Hydropsychidae at the Mae Tao and Mae Ku watersheds from July 2011 to May 2012.

\begin{tabular}{|c|c|c|c|}
\hline Site/parameter & $\begin{array}{c}\text { Cd in sediment } \\
\left(\mathrm{mg} \mathrm{kg}^{-1}\right)\end{array}$ & $\begin{array}{c}\text { Cd in Hydropsychidae } \\
\text { larvae }\left(\mathrm{mg} \mathrm{kg}^{-1}\right)\end{array}$ & $\begin{array}{c}\text { Cd in Hydropsychidae } \\
\text { adult }\left(\mathrm{mg} \mathrm{kg}^{-1}\right)\end{array}$ \\
\hline MT1 & $0.99 \pm 1.28^{\mathrm{a}}$ & $0.29 \pm 0.24^{\mathrm{a}}$ & $0.02 \pm .0 .05^{\mathrm{a}}$ \\
\hline MT2 & $0.32 \pm 0.16^{\mathrm{a}}$ & $0.70 \pm 0.77^{\mathrm{a}}$ & $0.02 \pm 0.01^{\mathrm{a}}$ \\
\hline MT3 & $21.5 \pm 27.68^{\mathrm{b}}$ & LOD & $0.02 \pm 0.03^{\mathrm{a}}$ \\
\hline MT4 & $8.56 \pm 3.59^{\mathrm{ab}}$ & $0.33 \pm 0.54^{\mathrm{a}}$ & $0.02 \pm 0.02^{\mathrm{a}}$ \\
\hline MT5 & $9.29 \pm 5.70^{\mathrm{ab}}$ & $0.65 \pm 0.52^{\mathrm{a}}$ & LOD $^{\mathrm{a}}$ \\
\hline MK2 & $0.12 \pm 0.05^{\mathrm{a}}$ & $0.07 \pm 0.17^{\mathrm{a}}$ & $0.02 \pm 0.01^{\mathrm{a}}$ \\
\hline
\end{tabular}

LOD $=$ Limit of detection $<0.020 \mathrm{mg} \mathrm{kg}^{-1}$

These areas were directly adjacent to riffle areas where Hydropsychidae larvae samples were collected. A $5 \mathrm{~cm}$ depth of sediment samples from several areas were collected and immediately sieved with native river water through a $60-\mu \mathrm{m}$ nylon mesh, transported to the laboratory on ice, and then dried at $60^{\circ} \mathrm{C}$. Radziemska and Fronczyk [27] revealed that the highest concentration of cadmium in the analyzed soil samples were noted at a depth of $0.00-0.10 \mathrm{~m}$; a reduction of approximately $19 \%$ occurred at $0.90-1.00 \mathrm{~m}$ at the sampling location $4.5 \mathrm{~m}$ from the pollution site.

Cadmium concentrations of all samples were analyzed by an inductively coupled plasma mass spectrophotometer (ICP-MS). The limit of cadmium detection was $<0.020 \mathrm{mg} \mathrm{kg}^{-1}$. Results were expressed as milligrams of metal per kilogram wet weight.

\section{Statistical Analysis}

Analysis of variance (ANOVA) was used to test for statistical differences between the means of cadmium concentration from the seven sampling sites. Duncan's multiple range test (DMRT) was also used for multiple comparisons of the means of the cadmium concentration in order to measure similarities of the sampling points. Cadmium concentrations in sediments were correlated with those in both larvae and adult Hydropsychidae using the nonparametric Spearman's correlation to evaluate the response of the biota to metals in sediments. All statistical tests were applied using SPSS software (version 15).

\section{Results and Discussion}

The cadmium concentrations obtained were in the 0.11-3.46 $\mathrm{mg} \mathrm{kg}^{-1}$ range, with an average of $0.99 \mathrm{mg} \mathrm{kg}^{-1}$ at MT1; MT2 values were in the $0.12-0 ; 50 \mathrm{mg} \mathrm{kg}^{-1}$ range, with an average of $0.32 \mathrm{mg} \mathrm{kg}^{-1}$; MT3 values were in the $2.43-76.45 \mathrm{mg} \mathrm{kg}^{-1}$ range, with an average of $21.50 \mathrm{mg}$ $\mathrm{kg}^{-1}$; MT4 values were in the $2.47-11.80 \mathrm{mg} \mathrm{kg}^{-1}$ range, with an average of $8.56 \mathrm{mg} \mathrm{kg}^{-1}$; MT5 values were in the $1.59-16.98 \mathrm{mg} \mathrm{kg}^{-1}$ range, with an average of $9.29 \mathrm{mg} \mathrm{kg}^{-1}$; MK2 values were in the $<0.020-0.20 \mathrm{mg} \mathrm{kg}^{-1}$ range, with an average of $0.12 \mathrm{mg} \mathrm{kg}^{-1}$; and MK8 values were in the 0.67-6.01 $\mathrm{mg} \mathrm{kg}^{-1}$ range, with an average of $3.44 \mathrm{mg} \mathrm{kg}^{-1}$ (Table 1). Cadmium concentration in stream sediment was significant at sites MT1, MT2, MK2, MK8, and MT3 $(P<0.05)$.

At the upstream site (MT2), the stream that flows through the zinc mines had lower levels of cadmium, which amassed into 21.5, 8.56, and $9.29 \mathrm{mg} \mathrm{kg} \mathrm{kg}^{-1}$ sediments downstream (MT3-MT5). The samples at MK8 situated on the other side of the mountain had cadmium concentration of $6.01 \mathrm{mg} \mathrm{kg} \mathrm{kg}^{-1}$, perhaps from phosphate fertilizers [28]. Roberts [29] reported that the phosphate fertilizers were generally the major source of trace metals among all inorganic fertilizers, and much attention had also been paid to the concentration of $\mathrm{Cd}$ in phosphate fertilizers. The use of fertilizers containing different concentrations of metals in different periods of cultivation, in addition to the deforestation of riparian vegetation, impacted the hydric resources of the adjacent areas, leading to contamination of the aquatic sediments. Metals introduced in the aquatic environment by agricultural activities around these areas can be absorbed and incorporated into the sediments. Every year, agricultural activities are carried out using fertilizers. This process causes severe damage to aquatic communities [30]. The stream sediment that was collected from MT1, the northeastern highland of zinc mining, found cadmium at a quantity of $0.99 \mathrm{mg} \mathrm{kg}^{-1}$. MK2, a stream in the southwestern highland, had a cadmium level of only $0.12 \mathrm{mg} \mathrm{kg}^{-1}$ (Table 1).

Although cadmium was detected in both larvae and adult Hydropsychidae, the obtained cadmium concentrations in hydropsychidae adults were negligible $\left(<0.020 \mathrm{mg} \mathrm{kg}^{-1}\right.$; Table 1). There were no significant differences of cadmium concentration in both larvae and adult Hydropsychidae from all sampling sites $(P>0.05$; Table 1$)$. The highest values for cadmium 


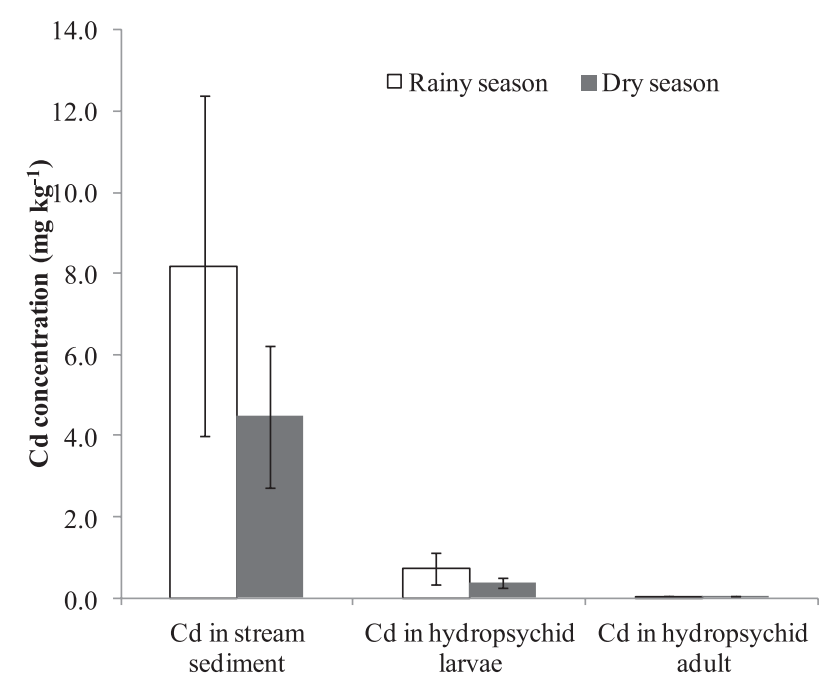

Fig. 2. Concentrations of cadmium in stream sediments, and both larvae and adult Hydropsychidae samples $(n=6)$ collected from the Mae Tao and the Mae Ku watersheds during the rainy and dry seasons (2011-2012)

concentrations in the hydropsychidae larvae were detected at site MK8 (mean concentration of approximately $1.70 \mathrm{mg} \mathrm{kg}^{-1}$ ). Cadmium was detected at very low values $\left(<0.020 \mathrm{mg} \mathrm{kg}^{-1}\right)$ in the hydropsychid larvae at site MT3.

Fig. 2 shows the distribution of cadmium levels in stream sediments and aquatic insect samples during the dry and rainy seasons in 2011-12 from the Mae Tao and Mae $\mathrm{Ku}$ watersheds. When cadmium concentrations were compared according to season, higher cadmium concentrations were found during the rainy season (July to November 2011) than the dry season (January to May 2012). The seasonal mean values of cadmium concentrations in stream sediment and aquatic insects ranged from $4.50,0.40$, and $<0.020 \mathrm{mg} \mathrm{kg}^{-1}$ in the dry season and $8.20,0.70$, and $<0.020 \mathrm{mg} \mathrm{kg}^{-1}$ in the rainy season. Krissanakriangkrai et al. [15] reported that cadmium concentrations in the rainy season were higher than in the dry season because of heavy rainfall leaching cadmium into the creek. The increased volume of cadmium from agricultural and mining waste entering the creek in the rainy season could have elevated metal bioavailability in water, which could in turn lead to increased bioaccumulation in aquatic insects.

No significant correlation was observed between aquatic insect and sediment cadmium concentrations (Table 2).
In the present study, cadmium concentrations in stream sediments showed differences in accordance with land use in the surrounding areas. Streams located in areas with mining and agricultural activities presented the highest concentrations of cadmium in the sediments and the larvae of aquatic insects. Cadmium is considered one of the most common contaminants in waters and its origin can be natural or anthropogenic. The anthropogenic origin may come from the industrial effluents and agricultural areas through leaching processes [31]. As the studied streams are located in the same hydrographic river basin with the same geological land formations [32], the highest values for metal concentrations detected were located in areas with mining activities. In Thailand, there are no maximum or minimum standard values for cadmium concentrations in sediments and for aquatic fauna.

Cadmium concentrations persist in various sections of the Mae Tao and Mae $\mathrm{Ku}$ watersheds. The analysis of the relationships of cadmium concentration in sediment and concentrations in both larvae and adult Hydropsychidae was negative. In most cases, cadmium levels in aquatic insects are not correlated to corresponding metal contamination. Only a few cases exist where metals in sediments were significantly related to those aquatic insects. Because organisms accumulate in only the biologically available species of the polluting metals, there is not always a correlation between metal concentrations in sediments with those in aquatic insects from the same sampling reach $[33,30]$. However, Pilo et al. [34] observed that a concentration gradient between metals in organisms and sediments is most often the same for all feeding guilds in rivers around the world.

Although cadmium concentrations in stream sediment showed no correlation with both larvae and adult Hydropsychidae, this heavy metal in stream sediment can be remobilized by the immature stages of the insects and transferred back to the water column through bioturbation or their metal burdens transferred to other aquatic organisms through predation. Research from Currie et al. [11] on emerging insects, including Diptera, Odonata, Ephemeroptera, and Trichoptera collected from the lake in 1991 indicated the exportation of cadmium from a natural system to the water and sediment. Transferred cadmium from the sediments by insects may be remobilized and become more available to aquatic organisms or enter the terrestrial ecosystem and subsequently impact insectivores.

Table 2. Spearman's correlation between cadmium concentrations in stream sediment, and in both larvae and adult Hydropsychidae in Mae Tao and Mae Ku watersheds from July 2011 to May 2012.

\begin{tabular}{|c|c|c|c|}
\hline & Cd in sediment & Cd in larvae Hydropsychidae & Cd in adult Hydropsychidae \\
\hline Cd in sediment & 1 & & \\
\hline Cd in larvae Hydropsychidae & 0.040 & 1 & \\
\hline Cd in adult Hydropsychidae & 0.147 & 0.036 & 1 \\
\hline
\end{tabular}




\section{Conclusions}

The results show the problems of cadmium accumulation caused in streams receiving mining effluence. This process may instigate severe harm to aquatic communities in the near future. In Thailand there are no reference values for cadmium concentration in sediments and for aquatic fauna. However, the results presented in this work uncovered high values of cadmium in the impacted areas, compared to the reference values for stream sediments. This work also tries to show the importance of the elaboration of a monitoring system that uses sediment as a compartment in environmental studies. Moreover, cadmium contamination in aquatic insects with a terrestrial adult life cycle, such as Trichoptera organisms, represent an important link for the transference of cadmium to upper trophic levels as fish, reptiles, birds, and mammals.

\section{Acknowledgements}

This research work was supported by the Thailand Research Fund (MRG5480221).

\section{References}

1. JAISHANKAR M., TSETEN T., ANBALAGAN N., MATHEW B.B., BEEREGOWDA K.N. Toxicity, mechanism and health effects of some heavy metals. Interdiscip Toxico. 7 (2), 60, 2014.

2. BURGER J. Assessment and management of risk to wildlife from cadmium. Sci Total Environ. 389, 37, 2008.

3. WEDYAN M. HARAHSHEH A.A., MUHAIDAT R. BSOUL E., QNAIS E. Cd and Fe Concentrations of the Surface Water of a Stream in Jordan. Pol J Environ Stud. 25 (6), 2617, 2016

4. MEBANE C.A., SCHMIDT T.S., BALISTRIERI L.S. Larval aquatic insect responses to cadmium and zinc in experimental streams. Environ. Toxicol. Chem. 36 (3), 749, 2017.

5. WESNER J.S., WALTERS D.M, SCHMIDT T.S., KRAUS J.M., STRICKER C.A., CLEMENTS W.H., WOLF R.E. Metamorphosis Affects Metal Concentrations and Isotopic Signatures in a Mayfly (Baetis tricaudatus): Implications for the Aquatic-Terrestrial Transfer of Metals. Environ. Sci. Technol. 51, 2438, 2017.

6. FLETCHER D.E., LINDELL A.H., STILLINGS G.K., BLAS S.A., MCARTHUR J.V. Trace element accumulation in lotic dragonfly nymphs: Genus matters. PLoS ONE, 12 (2), e0172016, 2017.

7. TSUI M.T.K., BLUM J.D., KWON S.Y., FINLAY J.C., BALOGH S.J., NOLLET Y.H. Sources and Transfers of Methylmercury in Adjacent River and Forest Food Webs. Environ Sci Technol. 46, 10957, 2012.

8. RAIKOW D.F., WALTERS D.M., FRITZ K.M., MILLS M.A. The distance that contaminated aquatic subsidies extend into lake riparian zones. Ecol Appl 21, 983, 2011.

9. MOGREN C.L, WALTON W.E., PARKER D.R., TRUMBLE J.T. Trophic transfer of arsenic from an aquatic insect to terrestrial insect predators. PLoS ONE. 8 (6), 1, 2013.
10. BECK M.L., HOPKONS W.A., JACKSON B.P. Variation in riparian consumer diet composition and differential bioaccumulation by prey influence the risk of exposure to elements from a recently remediated fly ash spill. Environ Toxicol Chem. 33 (11), 2595, 2014.

11. CURRIE R.S., FAIRCHILD W.L., MUIR D.C.G. Remobilization and export of cadmium from lake sediments by emerging insects. Environ Toxicol Chem. 16 (11), 2333, 1997.

12. WONGSANOON J. Cadmium contamination in Mae Tao stream in Amphur Mae Sod, Tak province. 118 p. The Graduate School of Social and Environmental Development, National Institute of Development Administration, Bangkok, Thailand. 2005.

13. CHANTHACHOT W., BUSAMONGKOL A., KHUNTONG S., PERIPART R., LOAHAROJANAPANAL S. Analysis of heavy metals in soil along Maetao river, Tak province by nuclear technique. In: Congress on Science and Technology, Thailand. 18-20 October 2005. 1, 2005.

14. SIMMONS R.W., PONGSAKUL P., SAIYASITPANICH D. Elevated levels of cadmium and zinc in paddy soils and elevated levels of cadmium in rice grain downstream of zinc mineralized area in Thailand: implications for public health. Environ. Geochem. Health. 27, 501, 2005.

15. KRISSANAKRIANGKRAI O., SUPANPAIBOON W., JUWA S., CHAIWONG S., SWADDIWUDHIPONG W., ANDERSON K.A. Bioavailable cadmium in water, sediment, and fish, in a highly contaminated area on the Thai-Myanmay Border. Thammasat. J. Sci. Tech. 14 (4), 60, 2009.

16. OTHMAN M.S., KHONSUE W., KITANA J., THIRAKHUPT K., ROBSON M.G., KITANA N. Cadmium accumulation in two populations of rice frogs (Fejervarya limnocharis) naturally exposed to different environmental cadmium levels. Bull. Environ. Contam. Toxicol. 83, 703, 2009.

17. Wiggins, G.B., CURRIE D.C. Trichoptera Families. In: Merritt, R.W., Cummins, K.W. \& Berg, M.B. (eds) An introduction to the aquatic insects of North America, $4^{\text {th }}$ edition. Iowa: Kendall/Hunt Publishing Company. 2007.

18. TSZYDEL M., MARKOWSKI M., \& MAJECKI J., BŁOŃSKA D., ZIELIŃSKI M. Assessment of water quality in urban streams based on larvae of Hydropsyche angustipennis (Insecta, Trichoptera) Environ Sci Pollut Res. 22, 14687, 2015.

19. HOSSEINI M., NABAVI S.M.B., PARSA Y. Bioaccumulation of Trace Mercury in Trophic Levels of Benthic, Benthopelagic, Pelagic Fish Species, and Sea Birds from Arvand River, Iran. Biol Trace Elem Res. 156, 175, 2013.

20. SRIPRACHOTE A., KANYAWONGHA P., OCHIAI K., MATOH T. Current situation of cadmium-polluted paddy soil, rice and soybean in the Mae Sot District, Tak Province, Thailand," Soil Science and Plant Nutrition, 1, 2012.

21. POLLUTION CONTROL DEPARTMENT. Cadmium contamination in Mae Tao Creek, Mae Sot District, Tak Province. Bangkok: Thailand Ministry of Natural Resources and Environment, 2004.

22. Distribution of cadmium and absorption by rice plants in areas nearby the zinc mine in Mae Sot District, National Research for Environmental and Hazardous Waste Management Chulalongkorn University, Bangkok: Chulalongkorn University, 2005.

23. SIMMONS R.W., SUKREEYAPONGSE O., NOBLE A.D., CHINABUT N. Report of LDD-IWMI land zoning and risk assessment activities undertaken in Phatat Pha Daeng 
and Mae Tao Mai Subdistricts, Mae Sot, Tak Province, Thailand," Bangkok: International Water Management Institute, 2005.

24. NAVARRO M.C., PÉREZ-SIRVENT C., MARTÍNEZSÁNCHEZ M.J., VIDAL J., TOVAR P.J., BECH J. Abandoned mine sites as a source of contamination by heavy metals: a case study in a semi-arid zone. J Geochem Explor. 96, 183e93, 2008.

25. PROMMI T. Descriptions of larvae of four species of Hydropsyche (Hydropsychidae: Trichoptera) from Thailand. Zootaxa, 4158 (4), 577, 2016.

26. PROMMI T., PERMKAM S. Larvae of Hydromanicus (Insecta: Trichoptera: Hydropsychidae) from Thailand, Zootaxa, 3914 (4), 467, 2015.

27. RADZIEMSKA M., FRONCZYK L. Level and contamination assessment of soil along an expressway in an ecologically valuable area in central Poland. Int $\mathbf{J}$ Environ Res Public Health, 12 (10), 13372, 2015.

28. AZZI V.S., KANSO A., KOBEISSI A., KAZPARD V., LARTIGES B., SAMRANI A.E. Effect of Cadmium on Lactuca sativa Grown in Hydroponic Culture Enriched with Phosphate Fertilizer. J Environ Prot. 6, 1337, 2015.

29. ROBERTS T.L. Cadmium and Phosphorous Fertilizers: The Issues and the Science. Procedia Eng. 83, 52, 2014.
30. CORBI J.J., FROEHLICH C.G. Bioaccumulation of metals in aquatic insects of streams located in areas with sugar cane cultivation. Quim. Nova. 33 (3), 644, 2010.

31. KHATRI N., TYAGI S. Influences of natural and anthropogenic factors on surface and groundwater quality in rural and urban areas. Front Life Sci, 8 (1), 23, 2015.

32. CORBI J.J., TRIVINHO-STRIXINO S., SANTOS A. Environmental Evaluation of Metals in Sediments and Dragonflies Due to Sugar Cane Cultivation in Neotropical Streams. Water Air Soil Pollut. 195, 325, 2008.

33. CISZEWSKI D., ALEKSANDER-KWATERCZAK U., POCIECHA A., SZAREK-GWIAZDA E., WALOSZEK A., WILK-WOŹNIAK E. Small effects of a large sediment contamination with heavy metals on aquatic organisms in the vicinity of an abandoned lead and zinc mine. Environ Monit Assess. 185, 9825, 2013.

34. PILO D., PEREIRA F., CARRICO A., CŬRDIA J., PEREIRA P., GASPAR M.B., CARVALHO S. Temporal variability of biodiversity patterns and trophic structure of estuarine macrobenthic assemblages along a gradient of metal contamination. Estuar Coast Shelf S, 167, 286, 2015. 